\title{
脂肪酵素に閔する研究 Studies on Lipase
}

第 2 報人留液脂肪酵素作用の臨床的觀察

Part II Clinical Study of Lipase Activity of Human Gastric Juice

(昭和 29 年 4 月 12 日受理)

斧 幡 定 雄
(Sadao Makihata)

緒論

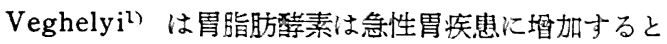
述べているが，高田”は無酸症の場合に，Delhougne ${ }^{3)}$ は過酸症の場合に胃脂肪酻素作用が障碍されるという。

併し一般に胃疾患の種類又之の程度に起因すると思惟 される人胃液脂肪徱素作用の警化に對する臨床的意義は 殆んど無いとされている。

著者は第一報に於て，人胃液脂肪酻素作用汇就て基磷 的研究の結果を報告したが，更に臨床的にも種々检索を 行つた。ここに各種疾患に於ける胃液分泌機能と胃液脂 肪醇素の消長に就て多數例の結果を得たので報告する。

從來, 胃或は十二指腸潰勗の治療には普遍的にアルカ リ療法が行われて來たか，其の後特殊なものとして Weiss 及び Aron ${ }^{4)}$ の創始したヒスチヂン療法, Cusic 及び Robinson ${ }^{5)}$ により合成され，Grimson ${ }^{6)}$ により滥 瘍治療に使用し始められた Banthine 療法, 次で Segal7) により制酸獄として伎用された陰イオン交換樹脂製劑で ある Stomaresin 嘹法がある。特に Banthine 及び Stomaresin の治療効果は大いに認められている。 從來胃分泌機能の檢查としては，何れも胃液の酸度・ 監酸量又暨素量の測定か;行われているが, 胃脂肪醖素の 消長以關する系統的な研究は未だその報告を關かない。

著者は胃並に十二指腸潰湯治療に當り，監酸七スチヂ ン, Banthine 及び Stomaresin の3 群に分ち治撩し， 治療前後の胃液中の遊離監酸度, 脂肪䣼素及びベプンン 作用に及ぼす影響を比較檢討したので，この結果をる併 せて報告する。

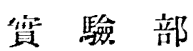

1）䁕助酵素測定：第 1 報に於て述べたと同樣に胃 ゾンデを用いて得た胃液を 3 倍量の蒸溜水にて稀釋した ものを醇素夜とした。

主筧驗； $8.0 \mathrm{ml}$. 綏㣫液 $+2.0 \mathrm{ml}$. 醉素液 $+0.4 \mathrm{ml}$. リアセチントトルーエン 3 摘（稀炭酸曹澾又稀苛性㫮達
液及じ稀暨酸を以て pH 5 に悠正した)。對照筫驗は醳 素を含まないもの或は基質を含まないものについて行つ た。各筫驗液を充分振湯混和して $37^{\circ} \mathrm{C}$. に溫置寸る。混 和直後々 12 時間溫置後の檢液 $5.0 \mathrm{ml}$. を取り，その酸 値坦加をフェノールフタレインを指示藥として $0.1 \mathrm{~N}$ 苛

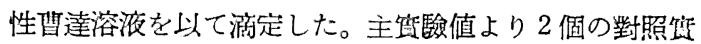
㯺值を控除せる值（酸値增加）を分解值として表に揭げ た。

2）遊離監酸度測定：0.5\% Dimethylamidazobenzol 一酒精溶液を指示藥とし，總酸度は1\% Phenol-phthalein 一酒精溶液を指示藥として，0.01 N 苛性曹澾液を以て滴 定した。

3）ペプシン測定： $2 \%$ 卵アルブミン溶液（Merck 製）を基質液とし， $0.1 \mathrm{~N}$ 歱酸を加えて $\mathrm{pH} 2$ とした。 主筫驗； $2.0 \mathrm{ml}$. 胃液 $+20 \mathrm{ml}$. 基質十トルーエン 3 滴。 對照筫驗； $2.0 \mathrm{ml}$. 蒸溜水 $+20 \mathrm{ml}$. 基質 + トルーエン 3 滴。 $2.0 \mathrm{ml}$. 胃液 $+20 \mathrm{ml}$. 蒸溜水十トルーエン 3 滴。

各試驗液の $\mathrm{pH}$ を 2 に修正し, 充分混和振温し, $37^{\circ} \mathrm{C}$. 12 時間溫置した。混和直後と 12 時間溫置後の检液 5.0 $\mathrm{ml}$. を取り，その酸值增加を Sörensen 氏 Formol 滴 定法により,フェノールフタレインを指示藥として $0.1 \mathrm{~N}$ 苛性曹達液を以て游定す。主筫豎値より二個の對照筫驗 值を控除した値（酸値堛加）を分解值としてぺプシン作 用を示す。

\section{成樍と考紧}

各種疾患に於ける胃分泌機能と脂肪䤃素の消長に就て 見るに, 胃脂肪醅素の消長は一定疾患との特別の關俰を 見出し難い。遊離嘫酸度 50 , 總酸度 70 以上を過酸症, 遊離橪酸度 20 , 總酸度 30 以下を減酸痛，その間を正酸 症と見て检討寸るならば，過酸疗の場合には一般に脂肪

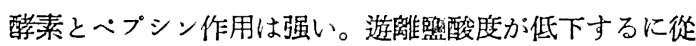
つて一般に脂肪醇素は弱くなつている(第 1 表)。過酸 症の場合にも胃脂肪酵素作用が障碍されるとい5 Delhougne ${ }^{3)}$ の報告があるか，著者の赛驗に於ては逆に增 
策㦈と食粗

第 1 表 各種薙患に於ける胃分泌機能と胃液脂肪䣼素 作用の消長（遊離㿼酸を証明する埸合）

\begin{tabular}{|c|c|c|c|c|}
\hline 䆙例 & 遊離 & 酸息 & 脂肪酸素 & ペプシン \\
\hline 健康 人 & 12 & 25 & 3.4 & 0.8 \\
\hline 慢性胃炎 & 6 & 24 & 0.85 & 0.55 \\
\hline 慢性胃炎 & 12 & 19 & 1.15 & 0.7 \\
\hline 胃 下垂 & 7 & 22.5 & 1.25 & 0.7 \\
\hline 胃下垂 & 41 & 52 & 5.95 & 0.8 \\
\hline 胃下垂 & 42 & 49 & 2.1 & 0.35 \\
\hline 峦 石 症 & 8 & 22 & 1.35 & 0.7 \\
\hline 脆 石 症 & 17.5 & 30 & 2.35 & 0.7 \\
\hline 腾石泟 & 22 & 33 & 2.0 & 0.8 \\
\hline 层石症 & 53.5 & 65.5 & 1.4 & 0.7 \\
\hline 膽 石 症 & 66 & 89 & 3.1 & 1.0 \\
\hline 單純性燕疸 & 6 & 17 & 1.1 & 0.4 \\
\hline 肝硬禁症 & 36.5 & 57.5 & 1.3 & 0.3 \\
\hline サルバル酸黃疸 & 38 & 50 & 3.9 & 0.75 \\
\hline 幽門痤杽 & 19 & 28 & 0.6 & 0.5 \\
\hline 䏣癌 & 8 & 28 & 1.5 & 0.7 \\
\hline 胃癌 & 13 & 27 & 6.55 & 0.7 \\
\hline 胃癌 & 14 & 28 & 2.3 & 0.55 \\
\hline 胃瘃 & 5 & 17.5 & 0.7 & 0.45 \\
\hline 胃癌 & 24.5 & 33 & 1.0 & 0.65 \\
\hline 胃＼cjkstart癌 & 44 & 57 & 3.7 & 0.6 \\
\hline 胃＼cjkstart癌 & 58 & 67 & 0.5 & 0.85 \\
\hline 十二脂腸清痬 & 4 & 14 & 3.2 & 0.55 \\
\hline 十二脂腸消瘍 & 15 & 35.5 & 0.9 & 0.8 \\
\hline 十二脂腸溃瘍 & 18 & 28 & 1.5 & 0.9 \\
\hline+ 二脂腸浩瘍 & 30 & 40 & 0 & 0.5 \\
\hline 十二脂腸溞瘍 & 42 & 54 & 1.35 & 0.65 \\
\hline 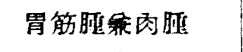 & 36 & 48 & 6.5 & 0.5 \\
\hline 罢 沮 瘍 & 5 & 14 & 1.95 & 0.55 \\
\hline 幽門浩痬 & 6 & 24 & 0.9 & 0.5 \\
\hline 幽門雖瘍 & 10 & 16 & 2.2 & 0.6 \\
\hline 幽門涄堭 & 11 & 18 & 0.25 & 0.75 \\
\hline 晭 溃 痬 & 14 & 26.5 & 0.6 & 0.4 \\
\hline 胃 溃瘳 & 18 & 28 & 1.15 & 0.4 \\
\hline 胃 溃 瘍 & 18 & 32 & 1.9 & 0.6 \\
\hline 胃馈痬 & 18.5 & 26.5 & 1.4 & 0.15 \\
\hline 胃 溃 湯 & 19.5 & 33 & 2.35 & 0.5 \\
\hline 胃 溜 劰 & 22 & 28 & 4.4 & 0.6 \\
\hline 胃溃 瘳 & 22 & 32 & 2.05 & 0.7 \\
\hline 冒 溃 場 & 22 & 32 & 0.4 & 0.35 \\
\hline 胃 溃 瘍 & 24 & 32 & 1.45 & 0.5 \\
\hline 兽 溃 稘 & 27 & 41 & 4.75 & 0.45 \\
\hline 胃 溃疸 & 29.5 & 37 & 1.45 & 0.8 \\
\hline 胃 浩 瘍 & 31 & 39.5 & 0.1 & 0.65 \\
\hline 胃 溃 湯 & 30.5 & 49 & 1.15 & 1.0 \\
\hline
\end{tabular}

角溃㾮

胃演演

胃溃演

等溃演

用滥演

胃惯湯

胃溃演

罢溃湯

胃溃瘍

胃滥場

幽門溃序

罢溃湯

胃港演

罢溃演

胃溃湯

胃湝疾

留溃暍

胃溃演

胃 掼 痬

胃溃湯

胃溃湯

胃溃瘍

胃溃瘍

胃 溃 痬

幽門㵋瘍

胃溃瘍

胃溃瘍

胃溃瘍

胃溃瘍

幽門惯瘍
俏溃演

胃溃痬

\begin{tabular}{c|l|l|l}
31 & 39.5 & 0.45 & 0.75 \\
31 & 40 & 0.4 & 0.7 \\
32 & 46 & 2.5 & 0.45 \\
34 & 40 & 4.4 & 0.6 \\
34 & 46 & 2.2 & 0.6 \\
34 & 47 & 4.25 & 0.6 \\
36 & 50 & 3.55 & 0.6 \\
36 & 43 & 1.65 & 0.95 \\
36 & 49.5 & 2.2 & 0.8 \\
37 & 49 & 4.25 & 0.6 \\
38 & 65 & 0.4 & 0.9 \\
38 & 48 & 3.85 & 1.0 \\
41 & 52 & 2.45 & 0.65 \\
46 & 54 & 2.9 & 0.45 \\
46 & 78 & 1.85 & 0.7 \\
46 & 54 & 4.8 & 0.9 \\
47 & 56 & 4.8 & 0.75 \\
48 & 59 & 4.7 & 0.6 \\
50 & 60 & 2.8 & 0.6 \\
52 & 62 & 6.8 & 0.85 \\
52 & 62 & 4.55 & 0.7 \\
52 & 64 & 1.6 & 0.6 \\
53 & 62 & 3.7 & 0.7 \\
53.5 & 62.5 & 0.35 & 0.35 \\
54 & 64 & 3.45 & 0.5 \\
54 & 65 & 5.55 & 0.85 \\
54 & 78 & 1.85 & 0.5 \\
63 & 71 & 1.35 & 0.45 \\
66 & 74 & 5.4 & 0.8 \\
70 & 82 & 3.25 & 0.65 \\
80 & 90 & 6.8 & 0.7 \\
170 & 112 & 1.2 & 0.75 \\
\hline & & & \\
34
\end{tabular}

第 2 表 各種疾患に於ける胃分泌機能と胃液脂肪醉案作 用の消長（遊離殟酸を證明しない場合）

\begin{tabular}{|c|c|c|c|c|c|}
\hline 㱏例 & 3 & 族䤃㢑 & 酸 & 脂肪醉素 & ヘプシン \\
\hline 胃 & 癌 & 0 & 2 & 0.2 & 0.5 \\
\hline 胃 & 㿋 & 0 & 14.5 & 0 & 0.6 \\
\hline 胃 & 属 & 0 & 11 & 0.05 & 0 \\
\hline 罥 & 癌 & 0 & 3.5 & 0 & 0 \\
\hline 胃 & 瘐 & 0 & 2 & 0 & 0 \\
\hline 胃 & 癌 & 0 & 4.5 & 0 & 0 \\
\hline 胃 & 癌 & 0 & 9 & 0.2 & 0.55 \\
\hline 胃 & 癌 & 0 & 12 & 0 & 0 \\
\hline 胃 & 痁 & 0 & 5 & 0 & 0.2 \\
\hline 胃 & 癌 & 0 & 1 & 0.1 & 0.05 \\
\hline 胃 & 瘦 & 0 & 11 & 0 & 0.2 \\
\hline 胃 & 痁 & 0 & 2 & 0.25 & 0.25 \\
\hline
\end{tabular}




\begin{tabular}{|c|c|c|c|c|}
\hline 虎 & 0 & 3 & 0.4 & 0 \\
\hline 癌 & 0 & 5 & 0.6 & 0.05 \\
\hline 癌 & 0 & 4 & 1.7 & 0.2 \\
\hline 瘦 & 1 & 14 & 1.2 & 0.3 \\
\hline 澏 & 1 & 10 & 0.45 & 0.45 \\
\hline 癌 & 1 & 7 & 0.3 & 0.25 \\
\hline 胃 & 8 & 56 & 0.2 & 0.4 \\
\hline 單純性黃疸 & 0 & 5 & 0.05 & 0 \\
\hline 單純性黄㾝 & 0 & 10 & 0 & 0.45 \\
\hline 單純性黄疸 & 0 & 7 & 0.1 & 0.1 \\
\hline 單純性黄疽 & 2 & 10.5 & 0.2 & $0 . \overline{7}$ \\
\hline 流行性肝炎 & 0 & 8 & 0.8 & 0.2 \\
\hline 十二脂腸溃晹 & 0 & 10 & 0 & 0.35 \\
\hline 十二脂腸溃痬 & 0 & 6.5 & 0 & 0.05 \\
\hline 十二脂腸潰㾮 & 0 & 5 & 0.6 & 0.45 \\
\hline 十二脂腸溃痬 & 0 & 4 & 0.4 & 0.2 \\
\hline 胃 下 垂 & 0 & 6.5 & 0.1 & 0.45 \\
\hline 胃 下 垂 & 0 & 4 & 0.3 & 0.95 \\
\hline 胃 下 垂 & 0 & 3 & 1.0 & 0.05 \\
\hline 慢性胃炎 & 0 & 3 & 0.55 & 0.4 \\
\hline 糖 沓 症 & 0 & 3 & 2.9 & 0.35 \\
\hline 胃 溃 痬 & 0 & 4 & 0.05 & 0 \\
\hline 胃 潰 瘍 & 0 & 6 & 1.2 & 0.5 \\
\hline 胃 馈 源 & 0 & 7 & 1.5 & 0.3 \\
\hline 胃 溃 痬 & 0 & 8 & 0.3 & 0 \\
\hline 胃 潰 瘍 & 5.5 & 11.5 & 0 & 0.5 \\
\hline
\end{tabular}

强している例が多い。極めて少数例では低下している場 合も見られた。

高田2!は無酸の場合は胃脂肪醏素を缼くと述べている が，著者の場合でも同樣に脂肪酵素値が零であるか，甚 だ弱い作用を示した。極めて少政例では正常值に近い值 のものもあつた。胃癌の胃液にも胃脂肪酵素を缺くと唱

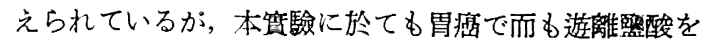
噔明しない例では，固脂肪酵素值は雾か又は非常に弱い

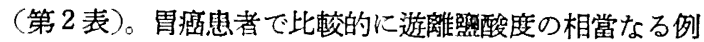
では，脂肪酵素作用が障碍されないものもあるが，癌胃 液に於て遊離暨酸が正常に䙞明されるに拘らず，胃脂肪 醭素作用が甚だ弱い例のある事は興味ある事と考えられ る、これは瘦發生の部位や浸獎された胃粘膜の公さが問 題になると思われる。今迄の碡究によると，豚では噴門 部に脂肪酵素が最も铻富とされている。併し反對に $\mathrm{Glick}^{8)}$ に依れば胃脂肪醭素の座生は胃各部均等で，噴 門部で特に多くはないと言い一定しない。著者の腯臨例 では幽門部又は幽門に近い部位の瘦が大部分で，噴門に 近い部位の例は甚だ少いので何とも言えない。

次に脂肪酔素並にヘプシン作用と遊離䜿酸に就て比較 して見ると，脂肪酵素の陰性或は殆んど證明されない場 台には遊離朁酸は常に零になつている。ペ゙ンンは脂肪 醇素の陰性の場合には大低陰性の事が多いが，弱い乍ら 陽性の事もある。脂肪醳素の出現頻度の方が少い樣であ

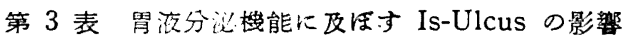

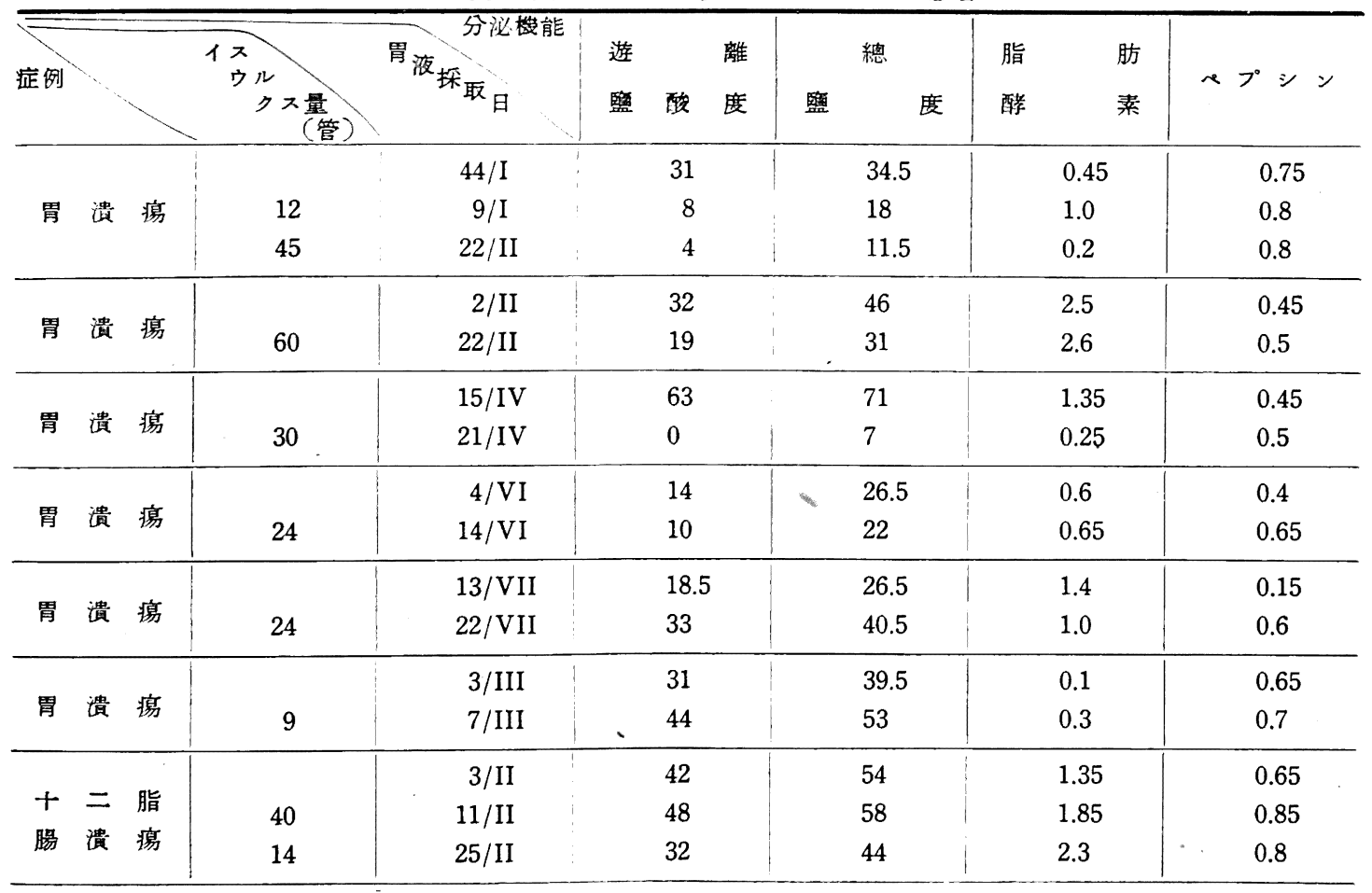




\begin{tabular}{|c|c|c|c|c|c|c|c|}
\hline 胃 & 癌 & 25 & $\begin{array}{r}6 / \mathrm{II} \\
12 / \mathrm{II}\end{array}$ & $\begin{array}{l}5 \\
0\end{array}$ & $\begin{array}{r}17.5 \\
9.9\end{array}$ & $\begin{array}{l}0.7 \\
1.0\end{array}$ & $\begin{array}{l}0.45 \\
0.45\end{array}$ \\
\hline 胃 & 癌 & 27 & $\begin{array}{r}2 / \text { III } \\
12 / \text { III }\end{array}$ & $\begin{array}{r}24.5 \\
3.5\end{array}$ & $\begin{array}{l}33 \\
14\end{array}$ & $\begin{array}{l}1.0 \\
1.2\end{array}$ & $\begin{array}{l}0.65 \\
0.65\end{array}$ \\
\hline 胃 & 癌 & 6 & $\begin{array}{l}23 / I X \\
26 / I X\end{array}$ & $\begin{array}{l}0 \\
0\end{array}$ & $\begin{array}{r}12 \\
5\end{array}$ & $\begin{array}{l}0 \\
0.25\end{array}$ & $\begin{array}{l}0 \\
0\end{array}$ \\
\hline
\end{tabular}

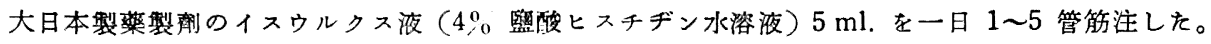

第 4 表 胃液分泌機能に及ほす Banthine の影䅉

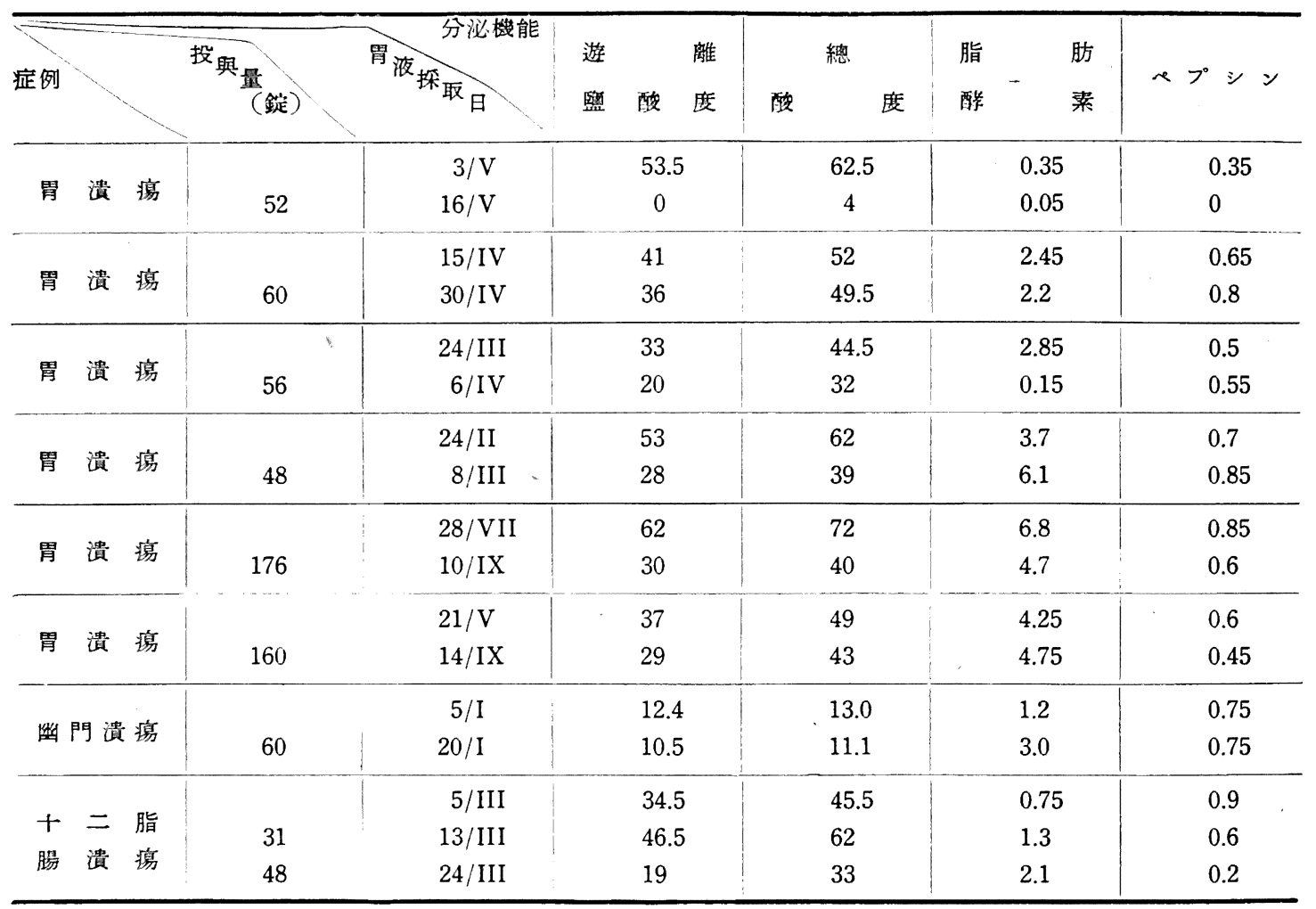

ジー・ディー・サール䘟（米國シカゴ），4〜8 錠（1 錠 $50 \mathrm{mg}$. 含有）を一日量として4回に分服せしめた。

第 5 表 胃液分泌機能に及ほすStomaresin の影幚

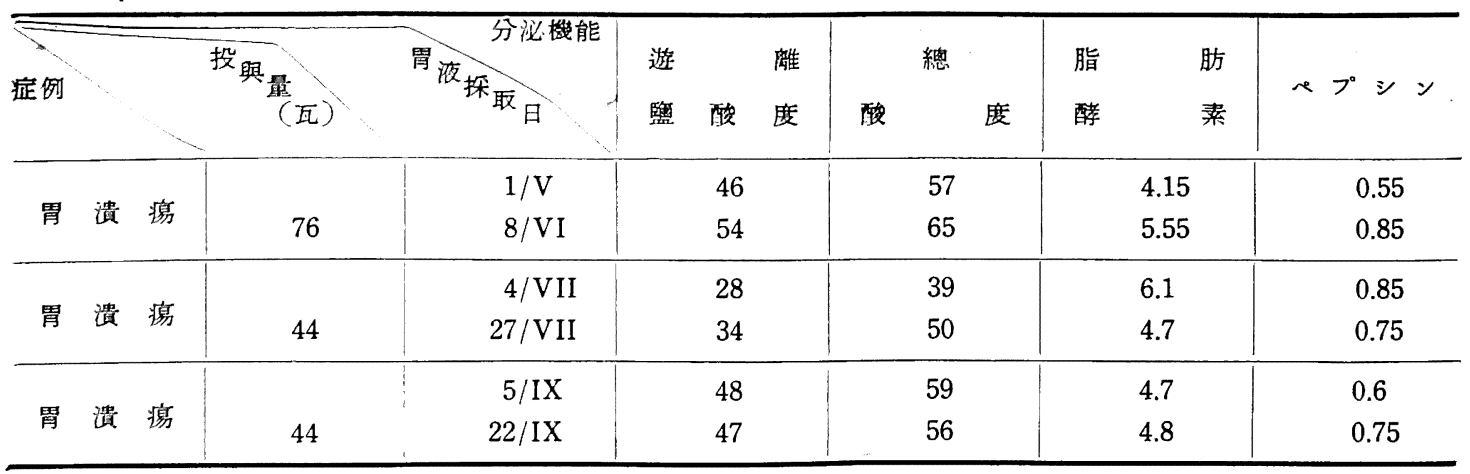

日本生物學研究所製劑のストマレジン 2 3.5gr. (一日黑) 4 回に分服せしめた。 
る。このベプシンと脂肪醇素分泌機能の晖離する例のあ ることは訫に知られている。甚だ少い例ではあるが，遊

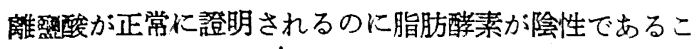
とも見られた。

头に胃文十二指腸溃第患者にイスウルクス $(5 \mathrm{ml} .4 \%$ 㼭酸ヒスチヂン溶液) を筋注した。注射は每日 1〜5 管 行い，注射前後に於ける胃液の分泌機能に及ぼす影鿆を 检查した。胃文十二指腸虫湯に對するヒスチヂン療法の 創始は，Weiss 及び Aron') の動物筫驗に於ける屝利な る觀察に起源する。氏等は更に種々の可能なる想定の許 に考案している。蛋白質の消化障碍によつて, 生踖內に 於て合成不可能の或るアミノ酸, 恐らくトリプトファン 及びヒスチヂンの领乏を來し，これか瀆惕の發生々原因 的關係を有すると見るのが最も妥當と考えた。

交献に依ると、イスウルクスの注射により，Winter ${ }^{9}$ は幾分胃酸度の低下を見た例があることを報告している か，豊島 ${ }^{10}$ は胃液分泌に對しては本療法は影響を及ぼさ ないと述べている。古川11は消化性潰场又過酸性胃炎に 於ては殆んど胃液酸度並に胃留酸分䎵狀態が低減に向え るを認めた。

著者の惯匳に於てはイスウルクス注射後，多數例に遊

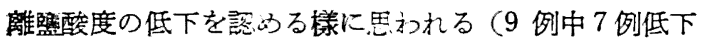
ᄂ, 2 例增加)。

この際ヘブシン作用は殆んど不㢣と思われるが，少數 例で脂肪䤃素作用の低下著しきものがあつた。脂肪醉素

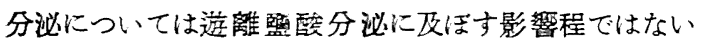
が，時として影暗を受ける結果を得たと思 万(第 3 表)。

Banthine は Cusic 及び Robinson ${ }^{5}$ により合成され たMethatheline bromideである。本物質はLongino ${ }^{12)}$ に依れば抗コリン作動性作用を有し，少量では副交感性 節後神經終末を遮斷し，アトロピン樣効果を表わす事が 報告された。從つて胃運動か抑制され，胃分泌機能に對 し抑制効果がある言う。

山形13は Katsch 及び Kalk のカフェイン試驗液を 用いて得られた胃液についての成綪では, 暨酸分泌對 する犃制勃果は輕度で，一過性に過ぎず，一部學者の主 張する樣に胃液分泌抑制によつて㣴疸症狀が輕快するも のとは見なし難いと述べている。松本 ${ }^{14)} は$ Banthine 投 與に依り胃液酸度低下著明なるのはなかつたと報告して いる。

著者は胃又十二指腸潰锡患者に Banthine 一日量 200 $\mathrm{mg} \sim 400 \mathrm{mg}, 1$ 週乃至 3 週間投與し, 胃分泌機能に及ほ

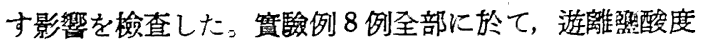
低下の倾向か認められた。特に 1 例に於ては遊離䑾酸度 が零となるが如き著明な抑制効果を認めた。ペプシン作 用は 8 例中， 4 例抑制， 2 例坦加， 2 例不變で，やや抑制
の倾向を認めた。脂肪醉素は 3 例诚少， 4 例增加，1 例

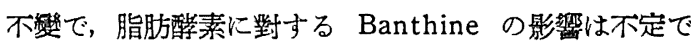
ある。併し遊離盤酸度の零となつた例では，脂肪醉素と ベプシン作用共に零となつたので，これは解酸，脂肪醉 素及びペプシン分泌機能の間に關係のある場合と考えら れる(第 4 表)。

1954 年 Segal7) か: Polyamine formaldehyde resin である一種の合成陰イオン交換レジンについて，胃液の 制酸効果並にその堛性の有無に關する研究を發表した。 その後此の種イオン交換レジンの臨床的㕍用が相次いで 研究された。それらの成績を綜括して見ると, 該レジン は酸中和の効果があるばかりでなく，同時に胃液の蛋白 消化酤素ヘプシンの作用をも抑制し，從つて胃溃煌の進 行を停止し，これを治癒する効果がることが明かに された。

著者は陰イオン交換樹脂制劑である Stomaresin「日 研」を胃潰疡患者に投與し，胃分泌機能に及ぼす影響を 檢した。

中島ひは Stomaresin 投與後のカフェイン胃液につ

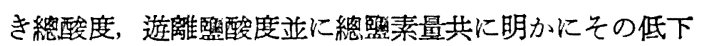
を認めたと言い, 又ヘプシン作用の抑制を報告している。 一方山形 ${ }^{15)}$ は過酸症患者に於て, 遊碓䑾酸度か; 20 以上 減少したものは $36.4 \%$ で，アルカリ劑使用によつて胃 液處見か好轉した $39.3 \%$ に比べると胃液酸度のみを對 照にすると輕快率は餘り良くないと述べている。之に反 し三浦 ${ }^{15}$ は胃潰湯患者で胃液酸度の低下を 15 例中 13 例 に婷めている。

著者は胃溃煌患者に一日量 2〜3.5gr.を 16 乃至 38 日 間投與して，Stomaresin の胃分泌機能に及ぼす影響を 檢した。その結果胃液の酸度, 肪肪醉素並にベプシン作 用について著明な變化を認めなかつた。併し症例が少く 決定的な斷定は困難と思 5 ので，更に多数例について觀 察したい(第 5 表)。

\section{綜括}

1）一般に過酸症の胃液に於ては胃脂肪醉素作用は强 力であるか，遊離暨酸度が低下寸るに從い脂肪醅素作用 は弱くなる。

2）無酸症及び胃瘦胃液に於ては胃脂肪酵素を欠く場 合加多い。

3）胃脂肪醇素作用の消長と一定疾患との關係は見出 乙難い。

4）無酸症の場合胃脂肪酻素とペプシン作用は大低陰 性であるか，この兩者は解離する場合がある。併し脂肪 醉素の出現頻度の方が少い。

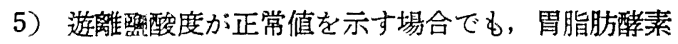


か陰性の事すある。

6）ヒスチヂンの胃分泌機能に及ぼす影響について は，䐬酸分泌並に胃脂肪酵素分泌は㧕制される傾向を見 たがヘブシン分泌には影響がないようである。

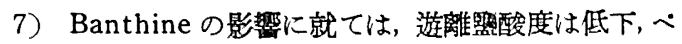
プシン分泌字抑制的傾向を示したか，胃脂肪酵素に及ぼ す影響は不定であつた。

8） Stomaresin の胃液の酸度, 脂肪酻素又へプシン

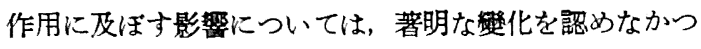
た。これは少數例のためかも知れないので試驗を挰充し たい。

\section{文献}

1) P. Vēghelyi; Ann. Paediat., 168, 93 (1947)

2) 高田; Zs. klin. Med., 98, 120 (1924)

3) Fr. Delhougne; D. Arch. Klin. Med., 152, 166 (1926)
4) Weiss, A. G. et Aron, E. ; Cpt. rend. soc. bil., 113, 1526 (1933)

5) Cusic \& Robinson; 117 th Meeting of Amev. Chem. Soc., (1950), Philadelphia (Grimson') $\mathrm{K}$ 上る)

6) K. S. Grimson; J. A. M. A., 143, 873 (1950)

7) Segal, H. L., Hodge, H., Watson, J. S. ; Gastroenterology, 4, 484 (1945)

8) D. Glick; Zs. phys. chem., 226, 186 (1934)

9) H. Winter; Med. K1., 31 (1935)

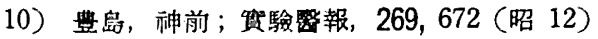

11）古川, 炭本; 兵闻醫學, 3,3 (昭 12)

12) Longino; Gastroenterol., 14, 301 (1950)

13）山形, 小泉; 䛦治療, 7, 41 (昭 28)

14）松本，武內；最新祭學，7，9（昭 27)

15) 中島, 山形, 三浦; 日消化器會誌, 50, 8 (昭 28)

(尼简病院)

\section{ATP の 定}

ATP の定量を化學的或は酻素的に行 5 方法として從 來いくつかの報告がのぺられている。酵素を用いるもの は, その特異性の上から微量の ATP 定量に關してずい 分高い感度の苴簽結果を與えているが，多くの方法は 2 種類の精製素を組み合せて行うすのであるためにど5 しても操作がはんざつになる娧いがある。

例えば

1) $\mathrm{ATP} \stackrel{\text { Phosphatase }}{\longrightarrow} \mathrm{AMP} \stackrel{\text { Deaminase }}{\longrightarrow} \mathrm{NH}_{3}$

. Hexokinase $Z$ wischenferment 2) ATP+Jlucose $\longrightarrow$ G. 6.P. $\underset{\mathrm{TPN}}{\longrightarrow}$ 6.P. G.

などがある。化學的方法は通常酸が水分解によつて遊離 して來る P を定量するものであるか，特異性が少い缺點 がある。ここに新に報告されたものは高等植物 pea seed （えんど5種子）から抽出精した Phosphoglyceric acid Kinase を用いて夯式による反應の追跡から ATP を定量せんと寸るすのである。この反應の平衡を完全に 右行せさるために $\mathrm{H}_{2} \mathrm{NOH}$ を加えて 1 . hydroxamic, 3 phosphoglyceric acid を作らせこれを比色的に定量 するのであるが，單一醭素による定量操作が何よりの利 點である。

3) $\mathrm{ATP}+3$. phosphoglyceric acid $\longrightarrow \mathrm{ADP}$ +1 . 3. diphosphoglyceric acid

盗驗例として發芽した mung bean では $0.246 \mathrm{mg} / \mathrm{g}$. fresh wt. が得られている。 The Determination of ATP by Meaus of Phosphoglgceric acid Kinase dy. W. Hollowag Arch. Biochem. Biophys. 57 (1954) 33.

（赤＼cjkstart燡）

\section{ペーパークロマトクラフによる glucose の定}

ペーパークロマトグラフであげた glucose を aniline hidrogenphthalote で發色させてから水醌酸で抽出し, スベクトロフォトメーターで比色定量する方法がのベら れている。比較的操作が簡單で時間を要せず，50〜200 $\gamma$ glucose の定量に關してはほとんど誤差なしで測定 出來る。
Quantitative Estimation of glucose by Paper Partition Chromatography by $\mathrm{S}$. Baar Biochem. J. 58 (1954) 175.

（赤 濢） 